\title{
THE ADSORPTION OF POTASSIUM AND PHOSPHATE IONS BY TYPICAL SOILS OF THE CONNEC- TICUT VALLEY
}

\section{BY ROBERT H. BOGUE}

It has been known for a long time that soils possessed the power of taking up or adsorbing certain salts from a solution, and a large amount of work has confirmed the fact that soils show a selective power of adsorption towards the different ions in the solution. ${ }^{1}$ Thus in general the positive ion is adsorbed to a greater extent than the negative, consequently leaving the soil solution in the acidic condition. This was formerly explained as a simple metathetical reaction-the bases of the soil and of the solution interchanging, or as the hydrogen of the complex organic acids known as humic acids being replaced by the base of the salt in the solution. That there is more or less interchange among the bases is easily shown by analysis to be true, but it has been repeatedly proven that the base liberated by the soil is usually not nearly equivalent to the base adsorbed from the solution. ${ }^{2}$ Although the acidity of the resulting soil solution may be explained by the former hypothesis as being due to the formation of an acid or an acid salt, yet it entirely fails to explain the latter fact of non-equivalent metathesis.

Moreover, soil is not the only substance which shows the power of selective adsorption. Cameron" has shown that metallic silver may be separated from a solution of silver nitrate by the selective adsorption of charcoal; and moist cotton entirely free from soluble acid will redden blue litmus paper left in contact with it for some time. Linder and

${ }^{1}$ Way: Jour. Roy. Agric. Soc. of Eng., I850, 313-79; Eichorn: Landwirtschafilches Central-Blatt., 2, I69 (1858); Biedermann and Rautlenberg: Jour. Landwirtschaft, New Series, 7, 49 (I862); Armsby: Am. Jour. Sci., (3) I4, $75(1877)$.

2 See references above.

3 "The Soil Solution," p. 66. 
Picton $^{1}$ and also Whitney and Ober ${ }^{2}$ have shown that when barium chlorid is used to precipitate arsenic trisulfid from colloidal solution, small amounts of barium are adsorbed, leaving in the solution a corresponding amount of free hydrochloric acid. These phenomena may be explained by attributing to the substances enumerated a special selective adsorbing power for the base in question, and Harris ${ }^{3}$ points out that the action of soils in the presence of soluble salts may be explained in the same way. Harris further points out the probability of this explanation from the action of electrolytes in general on colloids, for Linder and Picton ${ }^{4}$ have shown that the coagulation of negatively charged colloids is accompanied by the adsorption of the positively charged ion, and Coehn ${ }^{5}$ has shown that the colloids of the soil will in general be charged negatively since their dielectric constant, being solids, is less than that of water.

Thus the theory of selective adsorption has been steadily gaining ground, and in 1906 Schreiner and Failyer ${ }^{6}$ undertook a special study of several type soils with the intent of noting the effect of continued application of phosphate and potassium salt solutions, and subsequently of continued leaching, on the concentration of these salts in the soil solution. As a result they substantiated the theory developed by Schloesing, which is in brief, that the concentration of soluble salts in the free soil moisture is largely dependent on the adsorptive powers of the individual soils. The minerals of the soil yield, and apparently continue to yield, a solution whose concentration approaches equilibrium between the solution and the solid, but as true equilibrium probably never exists there must be other factors entering in to affect this state, as the area of soil directly exposed to the soil moisture during a limited period of time would pro-

${ }^{1}$ Jour. Chem. Soc., 67, 63 (1895).

"Jour. Am. Chem. Soc, 23, 842 (Igor).

s Jour. Phys. Chem., I8, 355 (1914).

${ }^{4}$ Jour. Chem. Soc., 67, 63 (1895).

SWied. Ann., 64, 217 (1898).

${ }^{6}$ Bur. of Soils, Bull. 32 (1906). 
duce a disturbance in the equilibrium. But the concentration of salts in the soil solution tends to remain practically constant for any given soil. Thus for example if the concentration of potassium in the soil moisture should be lessened by the leaching of heavy rains, or the taking up of potassium by the plants, or by any other cause, this concentration would quickly be reestablished by the soil giving up of its adsorbed potassium until the constant was again reached. Or if, on the other hand, the concentration of potassium in the soil solution should be increased, as by the application of a soluble fertilizer, or by evaporation of the soil moisture, the constant would be restored by the adsorption of the excess potassium by the soil.

As the results of Schreiner and Failyer show a rery marked difference between the adsorptive capacities of the different type soils used in their experiments, and inasmuch as "type soils" are not definite compounds, that is, a soil described as a fine sand from Maryland might be quite different from and have very different adsorptive capacities from a soil of the same description from Massachusetts, it was thought expedient to examine four of the most characteristic soils of the Connecticut Valley in order to determine their respective adsorptive capacities for potassium and phosphate ions, and to plot the adsorption and leaching curves for each type.

The soils studied in this investigation were a Windsor sand, a Podunk fine sandy loam, a Connecticut Meadow silt loam, and a Suffield clay.

The Windsor sand was obtained about a half mile north of Mount Orient on the Pelham Road. It is described ${ }^{1}$ as consisting of six to ten inches of light yellow or brown, coarse sand, resting on yellowish, coarse sand and fine gravel, slightly loamy. Its origin is considered to be a shallow lake deposit. There are two types of this sand: a light, loose form and a

${ }^{1}$ Soil Survey of the Connecticut Valley, Field Operations, Bur. of Soils 
heavier type which is more of a sandy loam. The former was the one studied.

The Podunk fine sandy loam was obtained about a mile west of the Massachusetts Agricultural College, and is described $^{1}$ as consisting of twelve inches of friable, dark brown, sandy loam, underlain with a yellow or brownish, fine, sandy loam. The material composing this soil originated by deposition in deeper lake waters, but has been largely reworked and redeposited by later stream action.

The Connecticut Meadow silt loam was obtained about a half mile west of North Amherst, on Meadow Street, and is described $^{2}$ as consisting of a dark silt loam in the upper twelve inches. This is underlain by a heavier dark grayish to yellow or brown silt loam. The material consists of the finest grades of sand and silt that have been reworked and deposited by the streams along which it flows. In the process of reworking and deposition large amounts of organic matter have been incorporated with the sand and silt.

The Suffield clay was obtained about one and a half miles west of Amherst Centre on Amity Street. It is described ${ }^{3}$ as consisting of four to eight inches of heavy, dark-drab clay loam resting on a heavy, tenacious, gray-drab clay, which extends to a depth of twenty and in some instances seventyfive feet. It is of deep lake origin, and while appearing very heavy and tenacious, it is largely composed of silt, probably of the finer grades.

The apparatus used in these experiments was essentially that used in the laboratory of the Bureau of Soils on similar investigations. ${ }^{4}$ The soil was placed within a nickel plated tube twelve inches long by one and a quarter inches inside diameter. A section of a Pasteur Chamberland filter was inserted at the lower end, the porous filter projecting about (I 903$)$.

${ }^{1}$ Soil Survey of the Connecticut Valley, Field Operations, Bur. of Soils

2 Ibid.

${ }^{3}$ Ibid.

${ }^{4}$ Schreiner and Failyer: U. S. Bur. of Soils, Bull. 32, I I (I906). 
one and a half centimeters above the rubber stopper, which held it in position. The upper part of the filter was plugged with a solid rubber stopper, while the lower end was fitted with a one hole stopper with a glass tube, through which the solution percolated. The upper end of the nickel tube was fitted with a two-hole stopper provided with two glass tubes. One of these was several feet in length, the length being determined by the pressure necessary to force the liquid through the filter at the desired rate, i. e., $50 \mathrm{cc}$ in 24 hours. This tube was connected by a syphon to a flask containing the solution to be passed through the filter. The shorter of the glass tubes was provided with a short piece of rubber tubing and a pinch cock, and served to let the air out of the tube when starting the experiment.

The samples of so: 1 were weighed out, mixed with distilled water to form a thin paste and this poured into the nickel tube. The tube was then connected with the rest of the apparatus, the syphon started, and a small Erlenmeyer flask provided to catch the percolate. By lengthening or shortening the height of the water column, and by the use of screw pinch cocks in the rubber connections, the desired rate of flow was obtained. The apparatus is shown in Fig. I.

Before a comprehensive study of the ad-

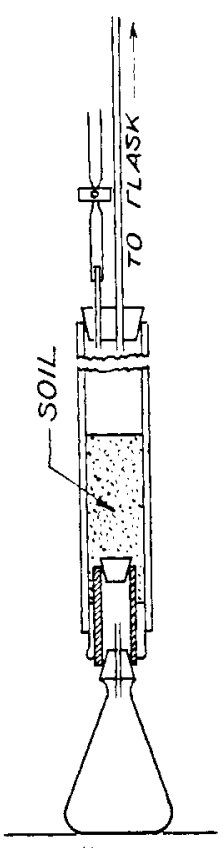

Fig. I sorption of soluble salts by the soil can be made, it is necessary to know how the salt in question, which the soil already contains, will be affected by the continued leaching with water. And it is also necessary in order to make a just comparison of the adsorption capacities of the various soils to have them all brought to a state of practical equilibrium, as regards their potassium and phosphate content, before beginning the adsorption experiments.

The tubes were therefore charged with Ioo grams of the 
soil, and pure, distilled water allowed to run through them at the rate of 50 cubic centimeters in 24 hours. The percolate was collected in fractions, and the potassium and phosphate content determined in each fraction. The method used in the determination of potassium was that described by Cameron and Failyer, ${ }^{1}$ which is based on the red color produced by the addition of an excess of potassium iodide to a solution of a platinic salt, as described by Morrell." "The method consists in precipitating the potassium as chlorplatinate, after removing ammonia by ignition, and washing this with alcohol in a manner similar to that followed in the usual gravimetric procedure. The chlorplatinate is dissolved in water, and the addition of potassium iodide develops the color above mentioned. The solution is then compared with a standard solution of potassium chlorplatinate in which the color has been similarly developed."

The method used in the determination of phosphate was that described by Schreiner and Brown." "It consists in converting the phosphate into magnesium ammonium phosphate, as is done in the usual gravimetric procedure, all silica, as well as other salts, and to a large extent also, soluble organic matter, being removed by washing with ammonia water. The magnesium ammonium phosphate is dissolved in nitric acid and determined by means of the yellow color produced by the addition of ammonium molybdate, comparing with a standard phosphate solution in which the color is similarly developed."

On testing out for the accuracy of these methods, a difference of three parts per million could usually be detected if the concentration in the sample was not greater than 200 parts per million. A higher concentration, however, especially in the case of potassium, rendered the results somewhat less accurate.

The results for the removal of potassium from the soils

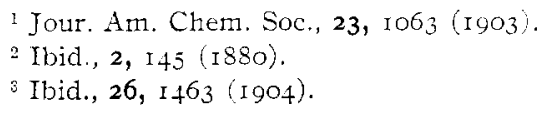


are given in Tables I, II, III and IV. In the first column is given the number of cubic centimeters in each individual fraction of percolate analyzed. In the second is given the total number of cubic centimeters that have passed through the filter. The third column shows the concentration of TABLE I

Removal of Potassium from a Sandy Soil

\begin{tabular}{|c|c|c|c|c|}
\hline $\begin{array}{l}\text { Volume of sol. } \\
\text { in sample } \\
\qquad c\end{array}$ & $\begin{array}{l}\text { Total volume of } \\
\text { solution } \\
\text { cc }\end{array}$ & $\begin{array}{l}\text { Potassium in } \\
\text { sample } \\
\text { p.p.m. of sol. }\end{array}$ & $\begin{array}{l}\text { Potassium in } \\
\text { sample } \\
\text { p.p.m. of soil }\end{array}$ & $\begin{array}{l}\text { Total potas- } \\
\text { sium extd. } \\
\text { p.p.m. of soil }\end{array}$ \\
\hline 55 & 55 & IO & 5 & 5 \\
\hline 45 & 100 & 7 & 3 & 8 \\
\hline 86 & I 86 & 6 & 5 & I 3 \\
\hline 86 & 272 & 6 & 5 & I 8 \\
\hline I I & 39 I & 3 & 4 & 22 \\
\hline I 29 & 520 & 4 & 5 & 27 \\
\hline I 34 & $65+$ & 4 & 5 & 32 \\
\hline I 86 & 840 & 3 & 6 & 38 \\
\hline I 66 & 1006 & 2 & 3 & $4 \mathrm{I}$ \\
\hline 252 & 1258 & 3 & 8 & 49 \\
\hline 332 & I 590 & I & 3 & 52 \\
\hline 522 & 2 I I 2 & 2 & IO & 62 \\
\hline I 888 & 4000 & I & I 8 & 80 \\
\hline & moval of $\mathrm{P}$ & $\begin{array}{l}\text { TABLE II } \\
\text { assium fron }\end{array}$ & ly Lo & \\
\hline
\end{tabular}

Volume of sol. Total volume of Potassium in Potassium in Total potas-

\begin{tabular}{|c|c|c|c|c|}
\hline in sample & $\begin{array}{l}\text { solution } \\
\mathrm{cc}\end{array}$ & $\begin{array}{c}\text { sample } \\
\text { p.p.m. of sol. }\end{array}$ & $\begin{array}{l}\text { sample } \\
\text { p.p.m. of soil }\end{array}$ & $\begin{array}{l}\text { sium ex } \\
\text { p.p.m. of }\end{array}$ \\
\hline 50 & 50 & 28 & $\mathrm{I}_{4}$ & $\mathrm{I}_{4}$ \\
\hline 54 & IO4 & 20 & I I & 25 \\
\hline IOS & 212 & I 6 & I 7 & +2 \\
\hline 78 & 290 & I 7 & I 3 & 5.5 \\
\hline I 27 & 417 & I 2 & 15 & \\
\hline I I I & 528 & 9 & 10 & 80 \\
\hline I 42 & 670 & 8 & I I & $9 \mathrm{I}$ \\
\hline 220 & 890 & 6 & $I_{3}$ & 104 \\
\hline 240 & I I 30 & 6 & I 4 & II 8 \\
\hline 350 & 1480 & t & I 4 & I 32 \\
\hline 8.54 & 2334 & 2 & I 7 & 149 \\
\hline 709 & $30+3$ & + & 28 & 177 \\
\hline 957 & 4000 & 3 & 29 & 20 \\
\hline
\end{tabular}


potassium in each of the fractions taken, expressed in parts per million of percolate. The fourth column expresses the amount of potassium extracted from the soil in each fraction, expressed in parts per million of soil, and the fifth column shows the total potassium extracted from the soil.

TABLE III

Removal of Potassium from a Silt Loam

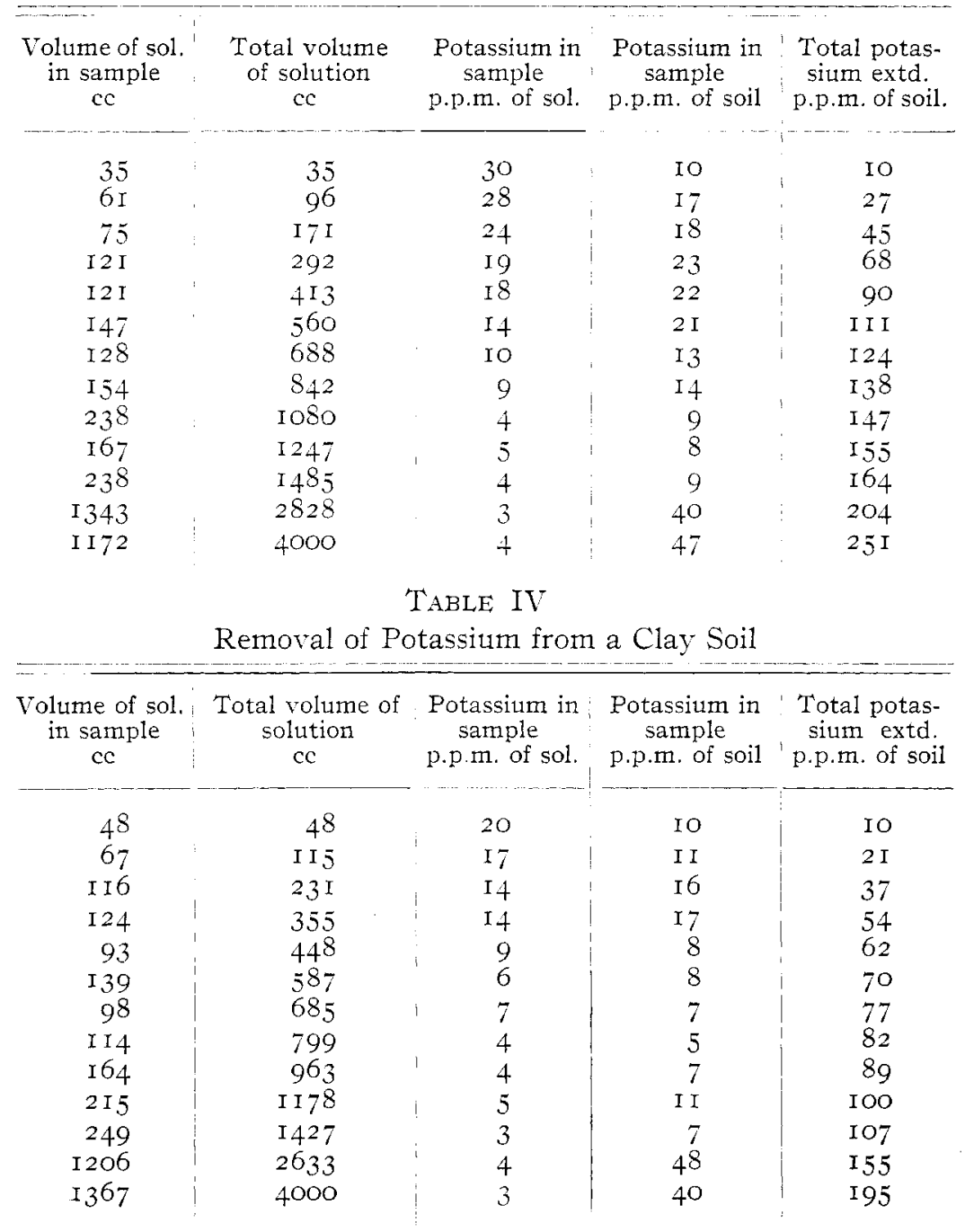


It will be noticed that the percolate from the sandy soil is very quickly brought down to a concentration which is practically constant, while in each of the other cases much more of the distilled water has to pass through before this constant is reached. The fact of there being a higher concentration of the potassium in the first few fractions is interesting. The assumption that this is due to readily soluble potash salts in the soil which are quickly leached out does not seem tenable in view of the adsorptive powers of the soils as will be shown later. The probable explanation of this higher concentration at the start lies in the fact that the soils were air dried before the leaching process was begun, and it has been demonstrated by Whitney and Cameron ${ }^{1}$ and later by King ${ }^{2}$ that oven- and air-dried soils would yield a larger quantity of soluble salts to water than would the same soils in the moist condition.

The results for the removal of phosphates from the four soils are given in Tables V, VI, VII and VIII. The main noticeable difference between the removal of the potassium and of the phosphate is that in the latter case the percolates from three of the four soils investigated increased somewhat in their phosphate content during the first part of the flow, whereas with the potassium the concentration in the percolate diminished regularly from the first. The same general tendency exists however as with the potassium, i. e., a fairly rapid diminution in the phosphate concentration to a certain point where it is maintained nearly constant.

After prolonging the preliminary leaching until four liters of water had passed through the soil, the tubes were allowed to drain completely, and these same soils were then treated in the same manner as before, one set with a solution of potassium chlorid and the other set with a solution of monocalcium phosphate, $\mathrm{CaH}_{4}\left(\mathrm{PO}_{4}\right)_{2}$. These solutions were made up to a strength of 200 parts per million of potassium $(\mathrm{K})$, and of phosphate $\left(\mathrm{PO}_{4}\right)$, respectively, and were prepared by

\footnotetext{
${ }^{1}$ Bur. of Soils, Bull. 22, 42 (1903).

2 Ibid., 26, 55 (I905).
} 


\section{TABLE V}

Removal of Phosphate from a Sandy Soil

\begin{tabular}{|c|c|c|c|c|}
\hline $\begin{array}{l}\text { Volume of sol. } \\
\text { in sample } \\
\text { cc }\end{array}$ & $\begin{array}{c}\text { Total yolume of } \\
\text { solution } \\
\text { cc }\end{array}$ & $\begin{array}{l}\text { Phosphate in } \\
\text { sample } \\
\text { p.p.m. of sol. }\end{array}$ & $\begin{array}{l}\text { Phosphate in } \\
\text { sample } \\
\text { p.p.m. of soil }\end{array}$ & $\begin{array}{l}\text { Total phos- } \\
\text { phate extd. } \\
\text { p.p.m. of soil }\end{array}$ \\
\hline $5^{2}$ & 52 & I 2 & 6 & 6 \\
\hline 50 & $\mathrm{IO} 2$ & IO & 5 & I I \\
\hline 55 & I 57 & 9 & 5 & I 6 \\
\hline 54 & $2 \mathrm{II}$ & 8 & 4 & 20 \\
\hline 82 & 293 & 7 & 6 & 26 \\
\hline IO4 & 397 & 5 & 5 & $3 I$ \\
\hline I 6 & 5 I3 & 5 & 6 & 37 \\
\hline I I 5 & 628 & 4 & 5 & 42 \\
\hline I I 3 & $74 \mathrm{I}$ & 4 & 4 & 46 \\
\hline I I 9 & 860 & 5 & 6 & 52 \\
\hline I 38 & 998 & 4 & 5 & 57 \\
\hline I I 7 & I I I 5 & 3 & 4 & 6 I \\
\hline 420 & I $_{535}$ & 4 & 17 & 78 \\
\hline 607 & $2 \mathrm{I} 42$ & 3 & r 8 & 96 \\
\hline 945 & 3087 & 2 & I9 & I I 5 \\
\hline 9 I 3 & 4000 & 3 & 27 & I 42 \\
\hline \multicolumn{5}{|c|}{$\begin{array}{c}\text { TABLE VI } \\
\text { losphate from }\end{array}$} \\
\hline
\end{tabular}

\begin{tabular}{|c|c|c|c|c|}
\hline $\begin{array}{c}\text { Volume of sol. } \\
\text { in sample } \\
\text { ce }\end{array}$ & $\begin{array}{l}\text { Total volume of } \\
\text { solution } \\
\text { ec }\end{array}$ & $\begin{array}{l}\text { Phosphate in } \\
\text { sample } \\
\text { p.p.m. of sol. }\end{array}$ & $\begin{array}{l}\text { Phosphate in } \\
\text { sample } \\
\text { p.p.m. of soil }\end{array}$ & $\begin{array}{l}\text { Total phos- } \\
\text { phate extd. } \\
\text { p.p.m. of soil }\end{array}$ \\
\hline 44 & 44 & 9 & 4 & 4 \\
\hline 47 & $9 \mathrm{I}$ & I 3 & 6 & IO \\
\hline 60 & $I_{5} \mathrm{I}$ & 16 & 9 & 19 \\
\hline 65 & 216 & 2 I & 14 & 33 \\
\hline 65 & $28 \mathrm{I}$ & I 8 & I 2 & 45 \\
\hline 92 & 373 & 15 & I 4 & 59 \\
\hline I I3 & 486 & I 2 & I 3 & 72 \\
\hline I06 & 592 & 9 & 9 & $8 \mathrm{I}$ \\
\hline I 2 I & 713 & 8 & IO & 9 I \\
\hline I 23 & 836 & 6 & 7 & 98 \\
\hline I 26 & 962 & 6 & 7 & IO5 \\
\hline I 29 & IO9 I & 6 & 8 & I I 3 \\
\hline 392 & I 483 & 5 & I9 & I 32 \\
\hline 578 & $206 \mathrm{I}$ & 5 & 29 & I 6 I \\
\hline 1079 & $3 \times 40$ & 4 & 43 & 204 \\
\hline 860 & 4000 & 4 & 34 & 238 \\
\hline
\end{tabular}


Adsorption of Potassium and Phosphate Ions, Etc. 675

TABLE VII

Removal of Phosphate from a Silt Loam

\begin{tabular}{|c|c|c|c|c|}
\hline $\begin{array}{l}\text { Volume of sol. } \\
\text { in sample } \\
\text { cc }\end{array}$ & $\begin{array}{l}\text { Total volume of } \\
\text { solution } \\
\text { ce }\end{array}$ & $\begin{array}{c}\text { Phosphate in } \\
\text { sample } \\
\text { p.p.m. of sol. }\end{array}$ & $\begin{array}{l}\text { Phosphate in } \\
\text { sample } \\
\text { p.p.m. of soil }\end{array}$ & $\begin{array}{l}\text { Total phos- } \\
\text { phate extd, } \\
\text { p.p.m. of soil }\end{array}$ \\
\hline 56 & $5^{6}$ & I 5 & 8 & 8 \\
\hline $5 \mathrm{I}$ & 107 & I 7 & 9 & 17 \\
\hline 44 & I 5 I & I 8 & 8 & 25 \\
\hline 49 & 200 & I 6 & 8 & 33 \\
\hline 74 & 274 & I4 & 10 & 43 \\
\hline $8 \mathrm{I}$ & 355 & I I & 9 & 52 \\
\hline 103 & 458 & IO & 10 & 62 \\
\hline I I I & 569 & 8 & 9 & $7 \mathrm{I}$ \\
\hline I I 3 & 682 & 7 & 8 & 79 \\
\hline IOI & 783 & 6 & 6 & 85 \\
\hline I 2 I & 904 & 4 & 5 & 90 \\
\hline$x 64$ & I068 & 6 & IO & yoO \\
\hline 422 & I 490 & 5 & $2 I$ & I 2 I \\
\hline 477 & I 967 & 4 & 19 & I 40 \\
\hline 1035 & 3002 & 4 & $4 I$ & I $8 \mathrm{r}$ \\
\hline 998 & 4000 & 4 & 40 & 221 \\
\hline \multicolumn{5}{|c|}{ TABLE VIII } \\
\hline
\end{tabular}

Volume of sol. Total volume of Phosphate in Phosphate in Total phosin sample solution sample sample phate extd.

cc cc p.p.m. of sol. p.p.m. of soil p.p.m. of soil

\begin{tabular}{|c|c|c|c|c|}
\hline 54 & 54 & 24 & 13 & I 3 \\
\hline 57 & I I I & 25 & I 4 & 27 \\
\hline 57 & I 68 & 25 & I4 & $4 \mathrm{I}$ \\
\hline 64 & 232 & 24 & I 5 & $5^{6}$ \\
\hline 57 & 289 & 23 & I3 & 69 \\
\hline 76 & 365 & 19 & I4 & 83 \\
\hline I 6 & $48 I$ & I 5 & I7 & IOO \\
\hline 109 & 590 & I 2 & I3 & I I 3 \\
\hline 106 & 696 & 9 & IO & I 23 \\
\hline I I 8 & $8 I_{4}$ & 8 & 9 & $\mathrm{I} 32$ \\
\hline I 7 & 931 & 7 & 8 & 140 \\
\hline I 39 & 1070 & 6 & 8 & I 48 \\
\hline 443 & I 5 I 3 & 7 & $3 I$ & 178 \\
\hline 598 & $2 \operatorname{III}$ & 6 & 36 & 214 \\
\hline 1006 & 3117 & 6 & 60 & 274 \\
\hline 883 & 4000 & 6 & 53 & 327 \\
\hline
\end{tabular}


diluting a stock solution which had previously been standardized by gravimetric analysis.

The results obtained in the adsorption of potassium are given in Tables IX, X, XI and XII. The first three columns are as in the eaching tables, i. e., Ist, the volume of percolate in the individual fraction; 2nd, the total volume of percolate which has passed through the soil when any given fraction is taken; and $3 \mathrm{rd}$, the concentration of potassium in the fraction of percolate taken. The $4^{\text {th }}$ column represents the amount of potassium adsorbed from the solution expressed in parts per million of solution, and is obtained by subtracting the concentration of the potassium in the solution, 3rd column, from 200, the concentration of the solution flowing through. The $5^{\text {th }}$ column represents the amount of potassium adsorbed by the soil, expressed in parts per million of soil. The last columin shows the total amount of potassium adsorbed, expressed in parts per million of soil, when any given fraction is taken.

TABLE IX

Adsorption of Potassium by a Sandy Soil

\begin{tabular}{|c|c|c|c|c|c|}
\hline $\begin{array}{l}\text { Volume of sol. } \\
\text { in sample } \\
\text { cc }\end{array}$ & $\begin{array}{l}\text { Total vol. } \\
\text { of solution } \\
\text { cc }\end{array}$ & $\begin{array}{c}\text { Potassium } \\
\text { in sample } \\
\text { p.p.m. of } \\
\text { sol. }\end{array}$ & $\begin{array}{l}\text { Potassium } \\
\text { adsorbed } \\
\text { p.p.m. of } \\
\text { sol. }\end{array}$ & $\begin{array}{l}\text { Potassium } \\
\text { adsorbed } \\
\text { p.p.m. of } \\
\text { soil }\end{array}$ & $\begin{array}{l}\text { Total potas- } \\
\text { sium adsorbed } \\
\text { p.p.m. of soil }\end{array}$ \\
\hline 43 & 43 & 3 & 197 & 85 & 85 \\
\hline 46 & 89 & 14 & I 86 & 86 & $17 \mathrm{I}$ \\
\hline 38 & I 27 & 26 & I 74 & 66 & 237 \\
\hline 64 & I9 I & 78 & 122 & 78 & 3 I 5 \\
\hline 106 & 297 & $I_{5} \mathrm{I}$ & 49 & $5^{2}$ & 367 \\
\hline I I 7 & 4 I 4 & 179 & $2 \mathrm{I}$ & 24 & 391 \\
\hline I I 6 & 530 & I 88 & I 2 & I 4 & 405 \\
\hline 92 & 622 & I 92 & 8 & 7 & $4 \mathrm{I} 2$ \\
\hline 95 & 717 & I93 & 7 & 7 & 4I9 \\
\hline 89 & 806 & 190 & IO & 9 & 428 \\
\hline IOI & 907 & I 94 & 6 & 6 & 434 \\
\hline 86 & 993 & I 93 & 7 & 6 & 440 \\
\hline 94 & 1087 & 198 & 2 & 2 & 442 \\
\hline 255 & I 342 & 197 & 2 & 8 & $45^{\circ}$ \\
\hline 296 & I6 38 & I99 & I & 3 & 453 \\
\hline 364 & 2002 & I 98 & 2 & 7 & 460 \\
\hline
\end{tabular}


Adsorption of Potassium and Phosphate Ions, Etc. 677

\section{TABLE X}

Adsorption of Potassium by a Sandy Loam

\begin{tabular}{|c|c|c|c|c|c|}
\hline $\begin{array}{l}\text { Volume of sol. } \\
\text { in sample } \\
\text { cc }\end{array}$ & $\begin{array}{l}\text { Total vol. } \\
\text { solution } \\
\text { cc }\end{array}$ & $\begin{array}{l}\text { Potassium } \\
\text { in sample } \\
\text { p.p.m. of } \\
\text { sol. }\end{array}$ & $\begin{array}{l}\text { Potassium } \\
\text { adsorbed } \\
\text { p.p.m. of } \\
\text { sol. }\end{array}$ & $\begin{array}{c}\text { Potassium } \\
\text { adsorbed } \\
\text { p.p.m. of } \\
\text { soil }\end{array}$ & $\begin{array}{l}\text { Total potas- } \\
\text { sium adsorbed } \\
\text { p.p.m. of soil }\end{array}$ \\
\hline 56 & 56 & 6 & I 94 & IO8 & 108 \\
\hline $5 \mathrm{I}$ & 107 & I 2 & I 88 & 97 & 205 \\
\hline 50 & 157 & 25 & I 75 & 87 & 292 \\
\hline 57 & 2 I 4 & 39 & I $6 \mathrm{I}$ & 92 & $3^{8} 4$ \\
\hline 53 & 267 & 70 & 130 & 69 & 453 \\
\hline 107 & 374 & I 29 & $7 \mathrm{I}$ & 76 & 529 \\
\hline I 24 & 498 & $\mathrm{I} 6 \mathrm{I}$ & 39 & 48 & 577 \\
\hline IO8 & 605 & 175 & 25 & 27 & 604 \\
\hline 106 & 712 & I 83 & 17 & I 8 & 622 \\
\hline 197 & 809 & 189 & I I & $2 \mathrm{I}$ & 643 \\
\hline IO2 & 9 I I & 190 & IO & IO & 653 \\
\hline I0 8 & IOI9 & 195 & 5 & 5 & 658 \\
\hline IO5 & I I 24 & 193 & 7 & 7 & 665 \\
\hline 310 & I 434 & 198 & 2 & 6 & $67 \mathrm{I}$ \\
\hline 287 & $\mathrm{I} 72 \mathrm{I}$ & I 96 & 4 & I I & 682 \\
\hline 334 & 2055 & 198 & 2 & 6 & 688 \\
\hline
\end{tabular}

Adsorption of Potassium by a Silt Loam

\begin{tabular}{|c|c|c|c|c|c|}
\hline $\begin{array}{l}\text { Volume of sol. } \\
\text { in sample } \\
\text { cc }\end{array}$ & $\begin{array}{c}\text { Total vol. } \\
\text { solution } \\
\mathrm{cc}\end{array}$ & $\begin{array}{l}\text { Potassium } \\
\text { in sample } \\
\text { p.p.m. of } \\
\text { sol. }\end{array}$ & $\begin{array}{l}\text { Potassium } \\
\text { adsorbed } \\
\text { p.p.m. of } \\
\text { sol. }\end{array}$ & $\begin{array}{l}\text { Potassium } \\
\text { adsorbed } \\
\text { p.p.m. of } \\
\text { soil }\end{array}$ & $\begin{array}{l}\text { Total potas- } \\
\text { sium adsorbed } \\
\text { p.p.m. of soil }\end{array}$ \\
\hline $5^{\mathrm{I}}$ & $5 \mathrm{I}$ & 4 & 196 & IOO & IOO \\
\hline 53 & 104 & IO & 190 & IOO & 200 \\
\hline 44 & 148 & I8 & 182 & 80 & 280 \\
\hline 63 & 2 I I & 29 & $\mathrm{I} / \mathrm{I}$ & I08 & 388 \\
\hline 59 & 270 & 44 & I 56 & 92 & 480 \\
\hline $9^{8}$ & 368 & 69 & I 3 I & I 28 & 608 \\
\hline I I 9 & 487 & 107 & 93 & I I I & 719 \\
\hline 106 & 593 & I 50 & 50 & 53 & 772 \\
\hline I I 3 & 706 & 164 & 36 & $4 \mathrm{I}$ & 813 \\
\hline IO9 & 8 I 5 & 179 & $2 \mathrm{I}$ & 23 & 836 \\
\hline I 23 & 938 & 187 & I 3 & 16 & 852 \\
\hline I 17 & I055 & 192 & 8 & 9 & $86 \mathrm{I}$ \\
\hline 107 & I I 62 & 195 & 5 & 5 & 866 \\
\hline 288 & $I_{450}$ & 193 & 7 & 20 & 886 \\
\hline 318 & I 768 & 195 & 5 & I 6 & 902 \\
\hline 292 & 2060 & 197 & 3 & 9 & 9 I I \\
\hline
\end{tabular}


TABLE XII

Adsorption of Potassium by a Clay Soil

\begin{tabular}{|c|c|c|c|c|c|}
\hline $\begin{array}{l}\text { Volume of sol. } \\
\text { in sample } \\
\text { cc }\end{array}$ & $\begin{array}{l}\text { Total vol. } \\
\text { solution } \\
\text { cc }\end{array}$ & $\begin{array}{l}\text { Potassium } \\
\text { in sample } \\
\text { p.p.m. of } \\
\text { sol. }\end{array}$ & $\begin{array}{l}\text { Potassium } \\
\text { adsorbed } \\
\text { p.p.m. of } \\
\text { sol. }\end{array}$ & $\begin{array}{l}\text { Potassium } \\
\text { adsorbed } \\
\text { p.p.m. of } \\
\text { soil }\end{array}$ & $\begin{array}{l}\text { Total potas- } \\
\text { sium adsorbed } \\
\text { p.p.m. of soil }\end{array}$ \\
\hline 35 & 35 & 4 & 196 & 68 & 68 \\
\hline $5 I$ & 86 & 6 & I 94 & 99 & 167 \\
\hline $4 \mathrm{I}$ & I 27 & 7 & 193 & 79 & 246 \\
\hline $6 I$ & I 88 & I I & 189 & I I 5 & $36 \mathrm{I}$ \\
\hline 77 & 265 & 20 & I 80 & I38 & 499 \\
\hline IO5 & 370 & 45 & I 55 & I 63 & 662 \\
\hline I 2 I & $49 I$ & 74 & I 26 & I 52 & $8 \mathrm{I} 4$ \\
\hline I 16 & 607 & I I I & 89 & IO3 & 917 \\
\hline 105 & 712 & I 4 I & 59 & 62 & 979 \\
\hline 97 & 809 & I 58 & 42 & $4 \mathrm{I}$ & 1020 \\
\hline 107 & 916 & 172 & 28 & 30 & 1050 \\
\hline I06 & $\mathrm{IO} 22$ & I 84 & I 6 & 17 & 1067 \\
\hline I69 & I I I I & 187 & I3 & 23 & 1090 \\
\hline $29 \mathrm{I}$ & I 482 & I9I & 9 & 26 & I I I 6 \\
\hline 309 & 1791 & I 93 & 7 & 28 & I I 44 \\
\hline 357 & $2 \mathrm{I} 48$ & I9I & 9 & 32 & I I 76 \\
\hline
\end{tabular}

It will be seen that the concentration of potassium in the percolate increases very rapidly from the start, but, however, with different degrees of rapidity for each soil, the percolates from the sandy soil increasing the most rapidly, the sandy loam next, the silt loam next, and the clay soil the slowest. This emphasizes two points: Ist, that the sandy soil reaches its state of saturation with respect to its potassium content in the shortest length of time, the clay soil taking the longest time to reach this condition; and 2 nd, that the total adsorptive capacity of the sandy soil is the lowest of the four soils, while that of the clay soil is the greatest, the clay soil adsorbing 1176 parts of potassium as against 460 parts for the sandy soil, 688 parts for the sandy loam, and 9I I parts for the silt loam, on the passage of nearly equal amounts of potassium chlorid solution.

The adsorption of phosphates is shown in Tables XIII, $\mathrm{XIV}, \mathrm{XV}$ and XVI.

The most striking difference noted between these figures 
Adsorption of Potassium and Phosphate Ions, Etc. 679

and those for the adsorption of potassium is that the adsorption of phosphate takes place very much slower. In fact, the clay soil is still adsorbing phosphate when nearly five liters of the solution have passed through it, while in the case of the potassium, one liter was nearly sufficient to saturate the same soil. The same general relationship holds between the different soils with respect to the rate of adsorption, and the total amount of phosphate adsorbed, as with the potassium adsorption.

It seems somewhat peculiar that in both cases the soils continue to adsorb the ions in question, in very small amounts it is true, long after their approximate points of saturation have been reached, and in practically constant quantities for any given soil. It seems probable that this continued apparent adsorption is due to a metathetical reaction between

\section{TABLE XIII}

Adsorption of Phosphate by a Sandy Soil

\begin{tabular}{|c|c|c|c|c|c|}
\hline $\begin{array}{l}\text { Volume of sol. } \\
\text { in sample } \\
\mathrm{cc}\end{array}$ & $\begin{array}{l}\text { Total vol. } \\
\text { solution } \\
\text { cc }\end{array}$ & $\begin{array}{l}\text { Phosphate } \\
\text { in sample } \\
\text { p.p.m. of } \\
\text { sol. }\end{array}$ & $\begin{array}{c}\text { Phosphate } \\
\text { adsorbed } \\
\text { p.p.m. of } \\
\text { sol. }\end{array}$ & $\begin{array}{l}\text { Phosphate } \\
\text { adsorbed } \\
\text { p.p.m. of } \\
\text { soil }\end{array}$ & $\begin{array}{l}\text { Total phos- } \\
\text { phate ad- } \\
\text { sorbed } \\
\text { p.p.m. of soil }\end{array}$ \\
\hline 56 & $5^{6}$ & 8 & 192 & 107 & 107 \\
\hline 48 & IO4 & I 5 & 185 & 89 & 196 \\
\hline 59 & I63 & 22 & 178 & 105 & 301 \\
\hline 65 & 228 & $4 \mathrm{I}$ & 159 & IO3 & 404 \\
\hline 108 & 336 & 80 & I 20 & I 30 & 534 \\
\hline I 35 & $47 \mathrm{I}$ & IO5 & 95 & I 28 & 662 \\
\hline I I 7 & 588 & I 32 & 68 & 80 & 742 \\
\hline 104 & 692 & r 33 & 67 & 70 & 8 I 2 \\
\hline I 33 & 825 & I 70 & 30 & 40 & 852 \\
\hline I I 2 & 937 & I68 & 32 & 36 & 888 \\
\hline I I 5 & 1052 & I 75 & 25 & 29 & 917 \\
\hline I 26 & I 78 & I 8 I & I9 & 24 & 94 I \\
\hline I I 7 & I 295 & I 86 & 14 & I 6 & 957 \\
\hline 266 & $\mathrm{I} 56 \mathrm{I}$ & I94 & 6 & I 6 & 973 \\
\hline 323 & I 884 & 190 & IO & 32 & 1005 \\
\hline 283 & $2 \mathrm{I} 67$ & I 95 & 5 & I 4 & IOI9 \\
\hline IOI 3 & 3180 & I97 & 3 & 30 & I049 \\
\hline 580 & 3760 & I 96 & 4 & 23 & Io72 \\
\hline 995 & 4755 & 198 & 2 & 20 & 1092 \\
\hline
\end{tabular}


TABLE XIV

Adsorption of Phosphate by a Sandy Loam

\begin{tabular}{|c|c|c|c|c|c|}
\hline $\begin{array}{l}\text { Volume of sol. } \\
\text { in sample } \\
\text { cc }\end{array}$ & $\begin{array}{l}\text { Total vol. } \\
\text { solution } \\
\text { ce }\end{array}$ & $\begin{array}{l}\text { Phosphate } \\
\text { in sample } \\
\text { p.p.m. of } \\
\text { sol. }\end{array}$ & $\begin{array}{l}\text { Phosphate } \\
\text { adsorbed } \\
\text { p.p.m. of } \\
\text { sol. }\end{array}$ & $\begin{array}{l}\text { Phosphate } \\
\text { adsorbed } \\
\text { p.p.m. of } \\
\text { soil }\end{array}$ & $\begin{array}{l}\text { Total phos- } \\
\text { phate ad- } \\
\text { sorbed } \\
\text { p.p.m. of soil }\end{array}$ \\
\hline 47 & 47 & 5 & I 95 & 92 & 92 \\
\hline 53 & IOO & 5 & I 95 & IO3 & I95 \\
\hline 56 & I 56 & I I & 189 & 106 & $30 I$ \\
\hline 73 & 229 & I 6 & I 84 & I 34 & 435 \\
\hline 69 & 298 & I9 & $18 \mathrm{I}$ & 125 & 560 \\
\hline II 9 & $4 I 7$ & 32 & 168 & 200 & 760 \\
\hline$I_{4}$ & $53 \mathrm{I}$ & 45 & I 55 & 177 & 937 \\
\hline 127 & 658 & 55 & I 45 & 184 & I I 2 I \\
\hline I 3 I & 789 & $7 \mathrm{I}$ & I 29 & 169 & I 290 \\
\hline 102 & $89 \mathrm{I}$ & 88 & I I 2 & I I 4 & $\mathrm{I} 4 \mathrm{O} 4$ \\
\hline I 26 & IOI 7 & 100 & IOO & 126 & I 530 \\
\hline I 49 & I I 66 & I 2 I & 79 & I I 8 & I 648 \\
\hline $\mathrm{IO}_{4}$ & 1270 & 135 & 65 & 67 & $17 I_{5}$ \\
\hline 226 & I 496 & 148 & 52 & II 7 & 1832 \\
\hline $32 \mathrm{I}$ & I 8 I 7 & 165 & 35 & I 12 & I944 \\
\hline 268 & 2085 & $I 72$ & 28 & 75 & 2019 \\
\hline 9 I 8 & 3003 & I 86 & $I_{4}$ & I 28 & 2147 \\
\hline 882 & 3885 & 190 & IO & 88 & 2235 \\
\hline 795 & 4680 & 192 & 8 & $7 \mathrm{I}$ & 2306 \\
\hline
\end{tabular}

the potassium chlorid or the monocalcium phosphate and some of the mineral constituents of the soil, as for example:

$$
\mathrm{NaAlSi}_{3} \mathrm{O}_{8}+\mathrm{KCl}=\mathrm{KAlSi}_{3} \mathrm{O}_{8}+\mathrm{NaCl} \text {, }
$$

and

$$
\mathrm{Ca}_{2} \mathrm{Al}_{2} \mathrm{Si}_{2} \mathrm{O}_{8}+\mathrm{CaH}_{4}\left(\mathrm{PO}_{4}\right)_{2}=\mathrm{H}_{4} \mathrm{Al}_{2} \mathrm{Si}_{2} \mathrm{O}_{8}+\mathrm{Ca}_{3}\left(\mathrm{PO}_{4}\right)_{2} .
$$

If this is the case it seems probable that as the experiments were carried out this apparent adsorption would continue indefinitely, or until all of the mineral matter of the soils that was capable of metathesis with the salts applied had undergone the reaction. Equilibrium could not be attained, inasmuch as the salt solutions entering are constantly percolating through and being replaced by fresh solution. This theory was not, however, worked out in any detail, but offers interesting material for further investigation.

After continuing the adsorption experiments for some time, 
Adsorption of Potassium and Phosphate Ions, Etc. 68I

TABLE XV

Adsorption of Phosphate by a Silt Loam

\begin{tabular}{|c|c|c|c|c|c|}
\hline $\begin{array}{c}\text { Volume of sol. } \\
\text { in sample } \\
\text { cc }\end{array}$ & $\begin{array}{l}\text { Total vol. } \\
\text { of solution } \\
\text { ce }\end{array}$ & $\begin{array}{l}\text { Phosphate } \\
\text { in sample } \\
\text { p.p.m. of } \\
\text { sol. }\end{array}$ & $\begin{array}{l}\text { Phosphate } \\
\text { adsorbed } \\
\text { p.p.m. of } \\
\text { sol. }\end{array}$ & $\begin{array}{l}\text { Phoshate } \\
\text { adsorbed } \\
\text { p.p.m. of } \\
\text { soil }\end{array}$ & $\begin{array}{l}\text { Total phos- } \\
\text { phate ad- } \\
\text { sorbed } \\
\text { p.p.m. of soil }\end{array}$ \\
\hline 57 & 57 & 4 & I 96 & I I 2 & I I 2 \\
\hline 47 & IO4 & 4 & 196 & 92 & 204 \\
\hline 59 & I 63 & 7 & I93 & I I 4 & 318 \\
\hline 56 & 219 & IO & 190 & I 06 & 424 \\
\hline I IO & 329 & I 5 & I 85 & 203 & 627 \\
\hline 127 & $45^{6}$ & $2 \mathrm{I}$ & 179 & 227 & 854 \\
\hline I IO & 566 & 40 & 160 & 176 & 1030 \\
\hline I I 8 & 684 & 43 & 157 & I 85 & $12 \times 5$ \\
\hline$I_{4} 4$ & 798 & 60 & 140 & 160 & I 375 \\
\hline I I 4 & 912 & 72 & 128 & 146 & $152 \mathrm{I}$ \\
\hline 120 & IO32 & 79 & I 2 I & I 45 & I 666 \\
\hline I 32 & I I 64 & 91 & 109 & I 44 & I 810 \\
\hline I 23 & 1287 & 102 & 98 & I 20 & 1930 \\
\hline 204 & I 49 I & I 20 & 80 & I 63 & 2093 \\
\hline 276 & I 767 & I 34 & 66 & I 82 & 2275 \\
\hline 279 & 2046 & 152 & 48 & 134 & 2409 \\
\hline 1002 & 3048 & 175 & 25 & 250 & 2659 \\
\hline 725 & 3800 & I $8 \mathrm{I}$ & 19 & I 43 & 2802 \\
\hline 896 & 4696 & I 86 & 14 & I 25 & 2927 \\
\hline
\end{tabular}

the apparatus was again disconnected and allowed to thoroughly drain as previously. Distilled water was then allowed once more to run through the soils, at the same rate, and the rate and extent of the leaching out of the potassium and of the phosphate noted.

The results for the leaching out of the potassium from the four soils are given in Tables XVII, XVIII, XIX and XX. The columns are arranged as in the tables of the preliminary leaching.

The leaching takes place very rapidly at first, diminishing in rate as more water passes through, much the same as in the preliminary leaching. But it is at once noticed that the amount of potassium which is thus readily leached out is not nearly equivalent to the amount which had previously been adsorbed by the same soil. By extended leaching the dis- 
TABLE XVI

Adsorption of Phosphate by a Clay Soil

\begin{tabular}{|c|c|c|c|c|c|}
\hline $\begin{array}{l}\text { Volume of sol. } \\
\text { in sample } \\
\text { cc }\end{array}$ & $\begin{array}{l}\text { Total vol. } \\
\text { of solution } \\
\text { cc }\end{array}$ & $\begin{array}{l}\text { Phosphate } \\
\text { in sample } \\
\text { p.p.m. of } \\
\text { sol. }\end{array}$ & $\begin{array}{l}\text { Phosphate } \\
\text { adsorbed } \\
\text { p.p.m. of } \\
\text { sol. }\end{array}$ & $\begin{array}{c}\text { Phosphate } \\
\text { adsorbed } \\
\text { p.p.m. of } \\
\text { soil }\end{array}$ & $\begin{array}{l}\text { Total phos- } \\
\text { phate ad- } \\
\text { sorbed } \\
\text { p.p.m. of soil }\end{array}$ \\
\hline 45 & 45 & 6 & I 94 & 87 & 87 \\
\hline 56 & IOI & 5 & 195 & IO9 & 196 \\
\hline 57 & I 58 & 6 & 194 & I IO & 306 \\
\hline 50 & 208 & 7 & I 93 & 96 & 402 \\
\hline IOI & 309 & I I & 189 & I9I & 593 \\
\hline 108 & 417 & I 7 & 183 & 208 & 801 \\
\hline I I 7 & 534 & 20 & 180 & $2 \mathrm{I} \mathrm{I}$ & IOI 2 \\
\hline I I 6 & $65^{\circ}$ & 27 & I 73 & $2 \mathrm{OI}$ & 1213 \\
\hline I 2 I & $77 \mathrm{I}$ & 40 & 160 & 193 & I 406 \\
\hline 122 & 893 & 46 & I 54 & I 88 & I 594 \\
\hline I 23 & IoI 6 & $5 I$ & 149 & I 83 & 1777 \\
\hline 134 & I I 50 & 52 & 148 & 198 & I975 \\
\hline I 22 & I 272 & 65 & I 35 & 165 & $2 \mathrm{I} 4 \mathrm{O}$ \\
\hline I I I & I 383 & 75 & I 25 & I 39 & 2279 \\
\hline 324 & 1707 & 97 & 103 & 334 & $26 \mathrm{I} 3$ \\
\hline 339 & 2046 & I I 5 & 85 & 288 & $290 \mathrm{I}$ \\
\hline 948 & 2994 & 148 & $5^{2}$ & 493 & 3394 \\
\hline 810 & 3804 & I 68 & 32 & 259 & 3653 \\
\hline 905 & 4709 & I 78 & 22 & I99 & 3852 \\
\hline
\end{tabular}

tilled water continues to take with it a small amount of potassium, but at a rate so slow that a very large amount of water would be required to extract all of the adsorbed potassium from the soil. The only explanation for this seems to be that the potassium which has been adsorbed has been converted into an insoluble compound which in turn goes back to the soluble form, but very slowly. This appears to be in accordance with the explanation previously given to account for the continued adsorption of the potassium and phosphate ions from the solution after the approximate point of saturation had been reached. The soil appears to be able to "take up " mineral salts in solution in two ways: ist, by adsorption, as we commonly understand the term, wherein the soil merely saturates itself, like a sponge, with the salts, these being readily soluble, and as easily washed out as taken up; and $2 \mathrm{nd}$, by 
Adsorption of Potassium and Phosphate Ions, Etc. 683

\section{TABLE XVII}

Removal of Adsorbed Potassium from a Sandy Soil

\begin{tabular}{|c|c|c|c|c|}
\hline $\begin{array}{l}\text { Volume of sol. } \\
\text { in sample } \\
\text { cc }\end{array}$ & $\begin{array}{c}\text { Total volume } \\
\text { of solution } \\
\text { cc }\end{array}$ & $\begin{array}{l}\text { Potassium } \\
\text { in sample } \\
\text { p.p.m. of sol. }\end{array}$ & $\begin{array}{l}\text { Potassium } \\
\text { in sample } \\
\text { p.p.m. of soil }\end{array}$ & $\begin{array}{l}\text { Total potassium } \\
\text { extracted } \\
\text { p.p.m. of soil }\end{array}$ \\
\hline 46 & 46 & $5^{8}$ & 27 & 27 \\
\hline 52 & 98 & 24 & 12 & 39 \\
\hline 53 & I5 I & I I & 6 & 45 \\
\hline 63 & $2 \mathrm{I} 4$ & I 2 & 8 & 53 \\
\hline 56 & 270 & 8 & 4 & 57 \\
\hline 45 & 3 I 5 & 8 & 4 & $6 \mathrm{I}$ \\
\hline 67 & 382 & 4 & 3 & 64 \\
\hline 88 & 470 & 5 & 4 & 68 \\
\hline 95 & 565 & 6 & 6 & 74 \\
\hline I 23 & 688 & 5 & 6 & 80 \\
\hline 192 & 870 & 4 & 8 & 88 \\
\hline 185 & 1055 & 5 & 9 & 97 \\
\hline 465 & I 520 & 4 & I 8 & II 5 \\
\hline 488 & 2008 & 3 & I 5 & I 30 \\
\hline
\end{tabular}

\section{TABLE XVIII}

Removal of Adsorbed Potassium from a Sandy Loam

\begin{tabular}{|c|c|c|c|c|}
\hline $\begin{array}{l}\text { Volume of sol. } \\
\text { in sample } \\
\text { cc }\end{array}$ & $\begin{array}{c}\text { Total volume } \\
\text { of solution } \\
\text { cc }\end{array}$ & $\begin{array}{l}\text { Potassium } \\
\text { in sample } \\
\text { p.p.m. of sol. }\end{array}$ & $\begin{array}{l}\text { Potassium } \\
\text { in sample } \\
\text { p.p.m. of soil }\end{array}$ & $\begin{array}{c}\text { Total potassium } \\
\text { extracted } \\
\text { p.p.m. of soil }\end{array}$ \\
\hline 35 & 35 & IOI & 35 & 35 \\
\hline 54 & 89 & 63 & 34 & 69 \\
\hline 53 & I 42 & 40 & $2 \mathrm{I}$ & 90 \\
\hline $5^{\mathrm{I}}$ & I93 & 34 & I 7 & 107 \\
\hline 55 & 248 & 25 & I4 & I $2 X$ \\
\hline $5 \mathrm{I}$ & 299 & 20 & IO & I 3 I \\
\hline 66 & 365 & I 8 & I 2 & I 43 \\
\hline 87 & 452 & I I & IO & I 53 \\
\hline 106 & 558 & I I & I 2 & 165 \\
\hline 89 & 647 & IO & 9 & 174 \\
\hline 185 & 832 & 8 & I 5 & 189 \\
\hline 180 & IOI 2 & 9 & 16 & 205 \\
\hline 468 & I 480 & 8 & 37 & 242 \\
\hline 522 & 2002 & 8 & $4^{2}$ & 284 \\
\hline
\end{tabular}


TABLE XIX

Removal of Adsorbed Potassium from a Silt Loam

\begin{tabular}{|c|c|c|c|c|}
\hline $\begin{array}{l}\text { Volume of sol. } \\
\text { in sample } \\
\text { cc }\end{array}$ & $\begin{array}{l}\text { Total volume } \\
\text { of solution } \\
\text { ce }\end{array}$ & $\begin{array}{l}\text { Potassium } \\
\text { in sample } \\
\text { p.p.m. of sol. }\end{array}$ & $\begin{array}{c}\text { Potassium } \\
\text { in sample } \\
\text { p.p.m. of soil }\end{array}$ & $\begin{array}{l}\text { Total potassium } \\
\text { extracted } \\
\text { p.p.m. of soii }\end{array}$ \\
\hline 43 & 43 & I I 4. & 49 & 49 \\
\hline $4^{8}$ & $9 I$ & 77 & 37 & 86 \\
\hline 56 & I 47 & $5^{6}$ & $3 \mathrm{I}$ & II 7 \\
\hline 53 & 200 & 40 & $2 I$ & I 38 \\
\hline 53 & 253 & $3^{6}$ & 19 & I 57 \\
\hline 56 & 309 & 28 & I 6 & I 73 \\
\hline 58 & 367 & $2 I$ & I 2 & I 85 \\
\hline $8 I$ & 448 & I 8 & I 5 & 200 \\
\hline 108 & 556 & I 5 & I 6 & 2 I 6 \\
\hline I I 6 & 672 & I 5 & I 7 & 233 \\
\hline 179 & $85 I$ & IO & I 8 & $25^{I}$ \\
\hline 187 & 1038 & I I & $2 \mathrm{I}$ & 272 \\
\hline 408 & I 446 & 9 & 37 & 309 \\
\hline $55^{2}$ & 1998 & 9 & 50 & 359 \\
\hline
\end{tabular}

\section{TABLE XX}

Removal of Adsorbed Potassium from a Clay Soil

\begin{tabular}{|c|c|c|c|c|}
\hline $\begin{array}{l}\text { Volume of sol. } \\
\text { in sample } \\
\text { cc }\end{array}$ & $\begin{array}{c}\text { Total volume } \\
\text { of solution } \\
\text { cc }\end{array}$ & $\begin{array}{l}\text { Potassium } \\
\text { in sample } \\
\text { p.p.m. of sol. }\end{array}$ & $\begin{array}{l}\text { Potassium } \\
\text { in sample } \\
\text { p.p.m. of soil }\end{array}$ & $\begin{array}{l}\text { Total potassium } \\
\text { extracted } \\
\text { p.p.m. of soil }\end{array}$ \\
\hline $5 \mathrm{I}$ & $5 \mathrm{I}$ & I 37 & 70 & 70 \\
\hline $4 I$ & 92 & 103 & 42 & I I 2 \\
\hline 46 & I 38 & 90 & $4 \mathrm{I}$ & I 53 \\
\hline 53 & I9I & 63 & 33 & I 86 \\
\hline $6 I$ & 252 & 57 & 35 & $22 \mathrm{I}$ \\
\hline 63 & 3 I 5 & 42 & 26 & 247 \\
\hline 71 & 386 & 38 & 27 & 274 \\
\hline 80 & 466 & 28 & 22 & 296 \\
\hline I 12 & 578 & 25 & 29 & 325 \\
\hline 106 & 684 & $2 \mathrm{I}$ & 22 & 347 \\
\hline I 88 & 872 & I9 & 36 & $3^{8} 3$ \\
\hline I 88 & I 060 & 18 & 34 & 417 \\
\hline 425 & I 485 & I 4 & 60 & 477 \\
\hline 545 & 2030 & I I & 60 & 537 \\
\hline
\end{tabular}


Adsorption of Potassium and Phosphate Ions, Etc. 685

metathesis, wherein the mineral constituents of the soil interact with the salts in the solution producing insoluble compounds which are reconverted into the soluble salts just as slowly as the soluble salts were first transformed into insoluble compounds, and are thus not readily washed out.

The results for the leaching of the phosphates are expressed in Tables XXI, XXII, XXIII and XXIV.

Here the phosphate is leached out, as in the case of the potassium, quickly at first, but becoming less and less rapid as the process continues. The main difference to be noted, however, is the much slower rate with which this is accomplished, the soils requiring about five times as much water to bring the phosphate content down to a constant. This large amount of water corresponds closely to the amount of solution required to bring the phosphate content up to a constant, during the adsorption process. The total amount of phosphate extracted when this constant is finally reached is,

\section{TABLE XXI}

Removal of Adsorbed Phosphate from a Sandy Soil

\begin{tabular}{|c|c|c|c|c|}
\hline $\begin{array}{l}\text { Volume of sol. } \\
\text { in sample } \\
\text { ce }\end{array}$ & $\begin{array}{c}\text { Total volume } \\
\text { of solution } \\
\text { cc }\end{array}$ & $\begin{array}{l}\text { Phosphate } \\
\text { in sample } \\
\text { p.p.m. of sol. }\end{array}$ & $\begin{array}{l}\text { Phosphate } \\
\text { in sample } \\
\text { p.p.m. of soil }\end{array}$ & $\begin{array}{l}\text { Total phosphate } \\
\text { extracted } \\
\text { p.p.m. of soil }\end{array}$ \\
\hline 52 & 52 & 185 & 96 & 96 \\
\hline 78 & I 30 & $I_{5}$ I & I 8 & 2 I 4 \\
\hline 76 & 206 & I I 8 & 90 & 304 \\
\hline IO9 & 315 & 89 & 97 & $40 \mathrm{I}$ \\
\hline 97 & 412 & 68 & 66 & 467 \\
\hline 138 & $55^{\circ}$ & 48 & 66 & 533 \\
\hline I 46 & 696 & 35 & $5 \mathrm{I}$ & 584 \\
\hline 183 & 879 & 24 & 44 & 628 \\
\hline I 25 & $100_{4}$ & 20 & 25 & 653 \\
\hline 236 & I 240 & I 2 & 28 & $68 \mathrm{I}$ \\
\hline 337 & 1577 & 9 & 30 & 7 II \\
\hline I $7 \mathrm{I}$ & 1748 & 8 & I4 & 725 \\
\hline 264 & 2012 & 8 & $2 I$ & 746 \\
\hline 604 & 2616 & 6 & 36 & 782 \\
\hline 608 & 3224 & 3 & 18 & 800 \\
\hline 784 & 4008 & 7 & 55 & 855 \\
\hline 702 & 4710 & 6 & 42 & 897 \\
\hline
\end{tabular}




\section{TABLE XXII}

Removal of Adsorbed Phosphate from a Sandy Loam

\begin{tabular}{|c|c|c|c|c|}
\hline $\begin{array}{l}\text { Volume of sol. } \\
\text { in sample } \\
\text { cc }\end{array}$ & $\begin{array}{c}\text { Total volume } \\
\text { of solution } \\
\text { cc }\end{array}$ & $\begin{array}{l}\text { Phosphate } \\
\text { in sample } \\
\text { p.p.m. of sol. }\end{array}$ & $\begin{array}{l}\text { Phosphate } \\
\text { in sample } \\
\text { p.p.m. of soil }\end{array}$ & $\begin{array}{l}\text { Total phosphate } \\
\text { extracted } \\
\text { p.p.m. of soil }\end{array}$ \\
\hline 48 & 48 & I 80 & 86 & 86 \\
\hline 59 & 107 & I6I & 95 & I 8 I \\
\hline 96 & 203 & I 39 & I 33 & $3 I_{4}$ \\
\hline 108 & 3 I I & I I 7 & 126 & 440 \\
\hline 97 & 408 & 95 & 92 & 532 \\
\hline I08 & 5 I 6 & $8 \mathrm{I}$ & 87 & 619 \\
\hline I 55 & $67 \mathrm{I}$ & 66 & IO2 & $72 \mathrm{I}$ \\
\hline I 79 & 850 & $5 \mathrm{I}$ & $9 \mathrm{I}$ & 8 I 2 \\
\hline I 44 & 994 & 39 & 56 & 868 \\
\hline 228 & 1222 & $3 \mathrm{I}$ & 71 & 939 \\
\hline 326 & I 548 & 19 & 62 & IOO I \\
\hline 203 & $175^{\mathrm{I}}$ & 12 & 24 & IO2 5 \\
\hline $25 I$ & 2002 & I I & 28 & 1053 \\
\hline 638 & 2640 & 8 & $5^{\mathrm{I}}$ & IIO4 \\
\hline 605 & 3245 & 8 & 48 & I I 52 \\
\hline 667 & 39 I 2 & 6 & 40 & I I 92 \\
\hline 809 & $472 \mathrm{I}$ & 7 & 57 & I 249 \\
\hline
\end{tabular}

\begin{tabular}{|c|c|c|c|c|}
\hline $\begin{array}{l}\text { Volume of sol. } \\
\text { in sample } \\
\mathrm{cc}\end{array}$ & $\begin{array}{c}\text { Total volume } \\
\text { of solution } \\
\text { cc }\end{array}$ & $\begin{array}{l}\text { Phosphate } \\
\text { in sample } \\
\text { p.p.m. of sol. }\end{array}$ & $\begin{array}{l}\text { Phosphate } \\
\text { in sample } \\
\text { p.p.m. of soil }\end{array}$ & $\begin{array}{c}\text { Total phosphate } \\
\text { extracted } \\
\text { p.p.m. of soil }\end{array}$ \\
\hline 57 & 57 & $\mathrm{I} 78$ & IOI & IOI \\
\hline 60 & I I 7 & I 59 & 95 & 196 \\
\hline 92 & 209 & 146 & I 34 & 330 \\
\hline IOO & 309 & I 28 & I 28 & $45^{8}$ \\
\hline I I 4 & 423 & IIO & I 25 & 583 \\
\hline I 2 I & 544 & 99 & I 20 & 703 \\
\hline I 3 I & 675 & 83 & IOg & 812 \\
\hline 178 & 853 & 72 & I 28 & 940 \\
\hline 174 & IO 27 & 63 & I IO & $105^{\circ}$ \\
\hline 234 & $\mathrm{I} 26 \mathrm{I}$ & 47 & IIO & I I 60 \\
\hline $27 \mathrm{I}$ & I 532 & 32 & 87 & I 247 \\
\hline I94 & 1726 & 28 & 54 & I 301 \\
\hline 263 & 1989 & 18 & 47 & I 348 \\
\hline 5 I 8 & 2507 & I 5 & 78 & I 426 \\
\hline 632 & 3139 & I 8 & $\mathrm{I} \mathrm{I}_{4}$ & I 540 \\
\hline 662 & $379 \mathrm{I}$ & IO & 66 & I 606 \\
\hline 937 & 4728 & 9 & 84 & I 690 \\
\hline
\end{tabular}


Adsorption of Potassium and Phosphate Ions, Etc. 687

\section{TABLE XXIV}

Removal of Adsorbed Phosphate from a Clay Soil

\begin{tabular}{|c|c|c|c|c|}
\hline $\begin{array}{l}\text { Volume of sol. } \\
\text { in sample } \\
\text { ce }\end{array}$ & $\begin{array}{c}\text { Total volume } \\
\text { of solution } \\
\text { ce }\end{array}$ & $\begin{array}{l}\text { Phosphate } \\
\text { in sample } \\
\text { p.p. m. of sol. }\end{array}$ & $\begin{array}{l}\text { Phosphate } \\
\text { in sample } \\
\text { p.p.m. of soil }\end{array}$ & $\begin{array}{l}\text { Total phosphate } \\
\text { extracted } \\
\text { p.p.m. of soil }\end{array}$ \\
\hline $5 \mathrm{I}$ & $5 I$ & I 74 & 89 & 89 \\
\hline $6 I$ & I I 2 & 166 & IOI & 190 \\
\hline IO4 & 216 & I 53 & I 59 & 349 \\
\hline 89 & 305 & I 46 & 130 & 479 \\
\hline 106 & 4 I I & I34 & I 42 & $62 \mathrm{I}$ \\
\hline 127 & 538 & 125 & I 59 & 780 \\
\hline 124 & 662 & I I 2 & I 39 & 919 \\
\hline I 86 & 848 & IOO & I 86 & I IO5 \\
\hline I 85 & IO33 & 87 & I $6 \mathrm{I}$ & I 266 \\
\hline $2 \mathrm{IO}$ & I 243 & 74 & I 55 & I $42 \mathrm{I}$ \\
\hline 285 & I 528 & 63 & I 80 & I60I \\
\hline 233 & $176 \mathrm{I}$ & 49 & I I 4 & I 7 I 5 \\
\hline 309 & 2070 & $4 \mathrm{I}$ & 127 & I 842 \\
\hline 519 & 2589 & 26 & I 35 & 1977 \\
\hline 603 & 3192 & $2 \mathrm{I}$ & 127 & $2 \mathrm{IO}_{4}$ \\
\hline 708 & 3900 & 16 & I I 3 & 2217 \\
\hline 878 & 4778 & I 5 & 132 & 2349 \\
\hline
\end{tabular}

however, far short of the amount of phosphate previously adsorbed, as was the case with the potassium.

These results may be expressed graphically, and in this form show, perhaps, the better advantage the similarities and differences which exist for the various soils, and under the different form of treatment.

In Fig. 2 are shown the solution curves for the preliminary leaching out of the potassium from the four soils under examination. The abscissas represent the liters of distilled water which have passed through the roo grams of soil in the percolating tubes, and the ordinates show the concentration of potassium, expressed in parts per million, of the resulting solution. The curves are all smoothed curves.

In Fig. 3 are shown the soil curves for the preliminary leaching. That is, the ordinates, instead of representing the concentration of potassium in the solution, indicate the amount of potassium which has been extracted from the soil, expressed 
in parts per million of soil. The abscissas, as before, represent the liters of water that have passed through the soils.

These figures show very clearly that after about one and a half liters of water have passed through the soils the concentration of potassium in the percolate is practically constant, and also that the soils are losing potassium at a slow but constant rate.



Fig. 2

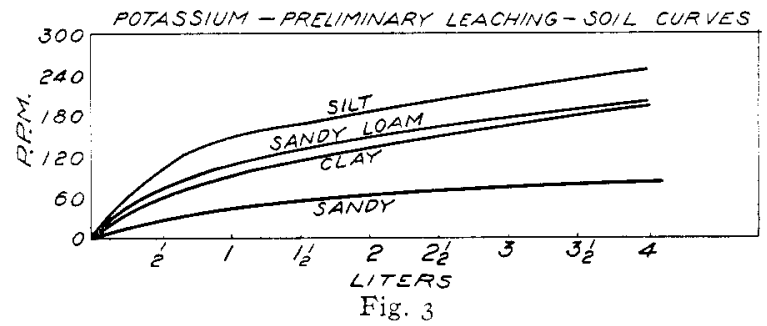

In Fig. 4 are shown the soln. curves for the adsorption of potassium ions, and in Fig. 5 the soil curves for the same. The ordinates in Fig. 4 represent the concentration of the solution in parts per million of potassium ions, the upper boundary line indicating the original concentration of the solution before passing through the soil. In Fig. 5 the ordinates show the amount of potassium that has been adsorbed by the soils, expressed in parts per million of soil. The abscissas in both cases represent the liters of solution that have passed through.

Here again, after about a liter of solution has passed through the soils the concentration in the percolates is constant and the soils continue to adsorb the potassium at a slow but constant rate. The differences in the adsorptive capacity of the 
Adsorption of Potassium and Phosphate Ions, Etc. 689

four soils are also very clearly brought out by these curves, the sandy soil being nearly saturated when only 400 parts per million have been adsorbed, while the clay soil does not approach the horizontal position until over a thousand parts have been adsorbed.

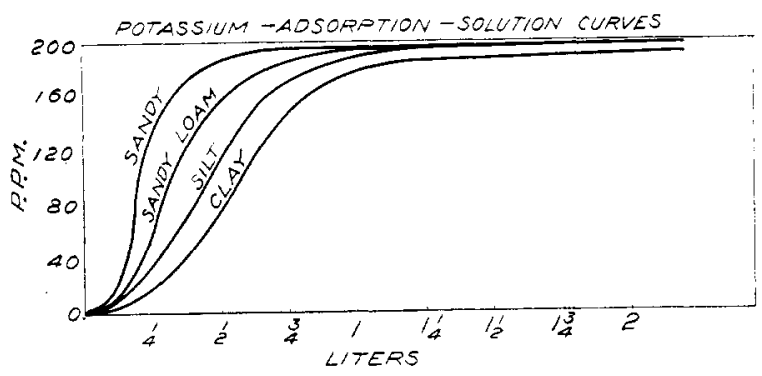

Fig. 4



Fig. 5

In Figs. 6 and 7 are given the solution and soil curves for the final leaching out of the potassium. The ordinates in Fig. 6 show the concentration of potassium in the solution, while in Fig. 7 they represent the amount of potassium leached out of the soils. The abscissas show the liters of water which have passed through.

Instead of starting the leaching curves at the point represented by the end of the adsorption curves, i. e., from a point representing the total amount of potassium adsorbed, they have been started uniformly from the same point, zero, the rise in the curves indicating the amount of potassium 
leached out. A more accurate comparison of the behavior of the different saturated soils, when treated similarly with distilled water, may be made by plotting them in this manner:

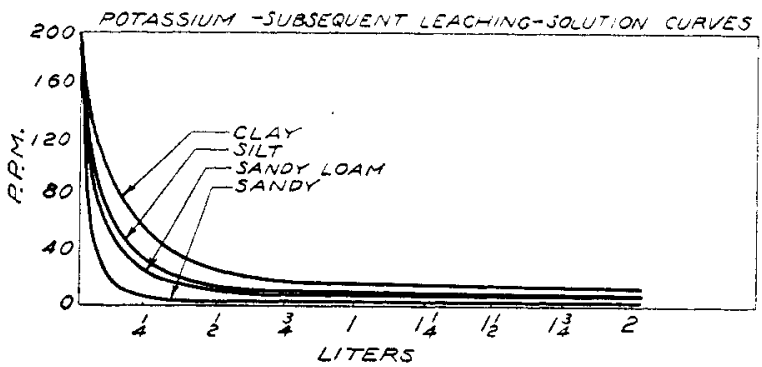

Fig. 6

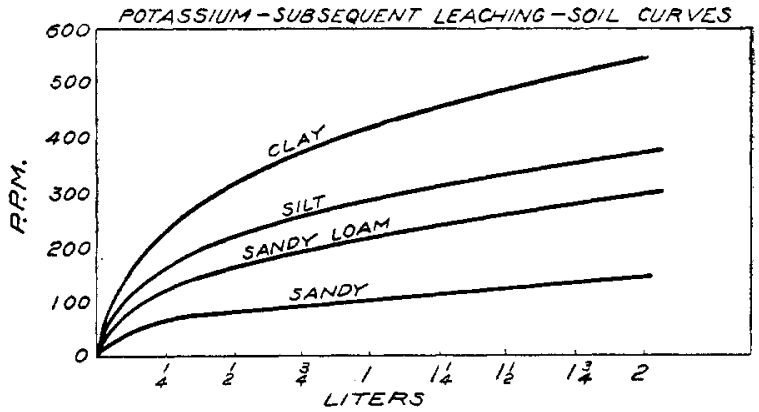

Fig. 7

It will be seen that a part of the potassium is very quickly removed on the passage of water through the soils, but that even by continued treatment with water only a fraction of the total amount of potassium adsorbed is removed, the parts per million of adsorbed potassium still remaining in the sandy soil after two liters of water have passed through it being 330 , and that remaining in the clay soil being 639 .

It will also be noticed taht the concentration of potassium in the percolate gets down very close to the constant attained in the original leaching, and that the soils attain a constant rate of loss, with reference to their potassium content, which is practically the same as the rate of loss in the original leaching. But the important point is that the soils still retain 
a large percentage of the potassium adsorbed by them, even after these constants are reached.

In Figs. 8 and 9 are shown the solution and soil curves for the preliminary leaching of the phosphate from the soils. The abscissas and ordinates represent in each case the same factors as in the corresponding plots with potassium, only, of course, phosphate is indicated instead of potassium.

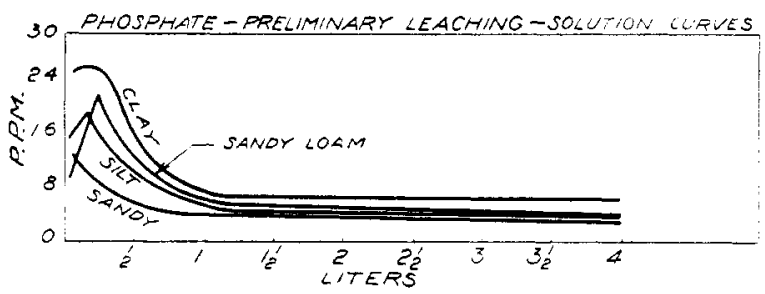

Fig. 8

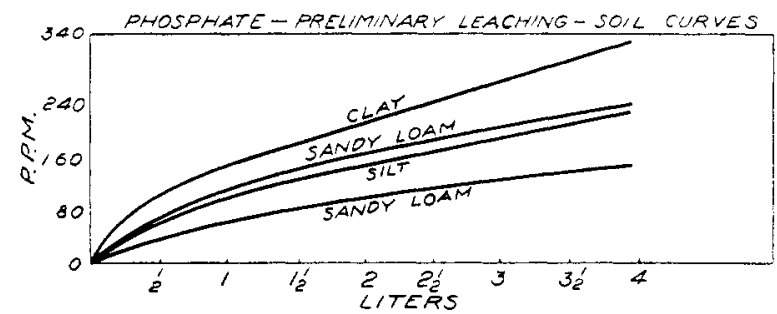

Fig. 9

The peculiar rise in phosphate concentration of the solutions from three of the soils is an apparent unconformity with the rest of the curve. The same general tendency exists, however, as in the potassium experiments, the percolate quickly falling to a constant concentration, and the soils attaining a slow but constant rate of loss in their phosphate content.

In Figs. IO and I I are shown the solution and soil curves for the adsorption of phosphate.

These curves differ markedly from the corresponding curves for potassium in the rate with which the soils become saturated, and also in the total amount adsorbed. Here the clay soil is still rapidly adsorbing phosphate when nearly five 
liters of solution have passed through it, while the same soil has reached its constant with respect to potassium when only about one liter has passed through. And when two liters of phosphate solution have passed through the clay soil it has adsorbed 2800 parts of phosphate, while when an equal amount of potassium solution has passed through the same soil, only I I 50 parts of potassium have been adsorbed.
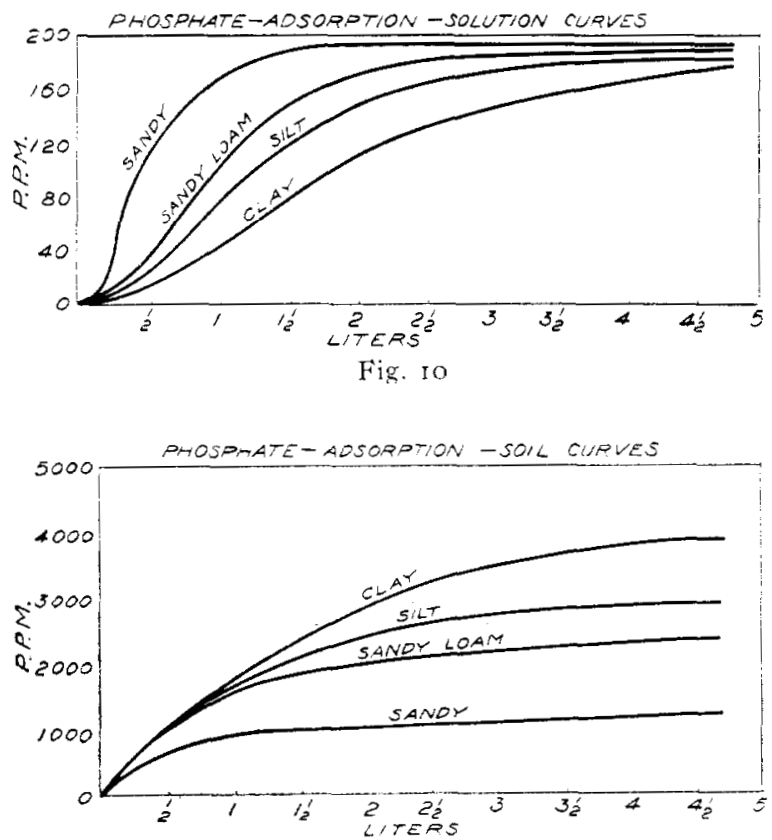

Fig. I I

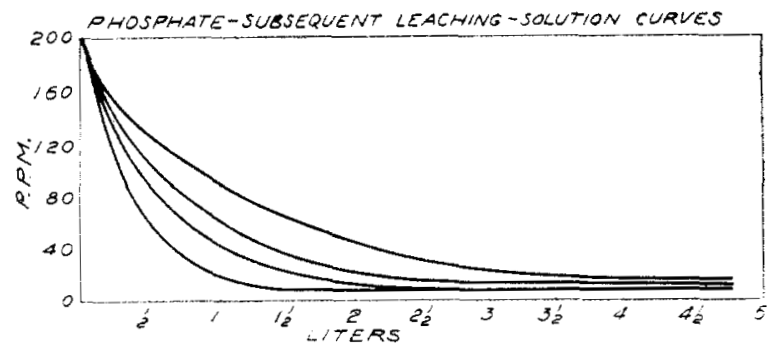

F*i: 12 
In Figs. I 2 and 13 are shown the solution and soil curves for the final leaching out of the phosphate.

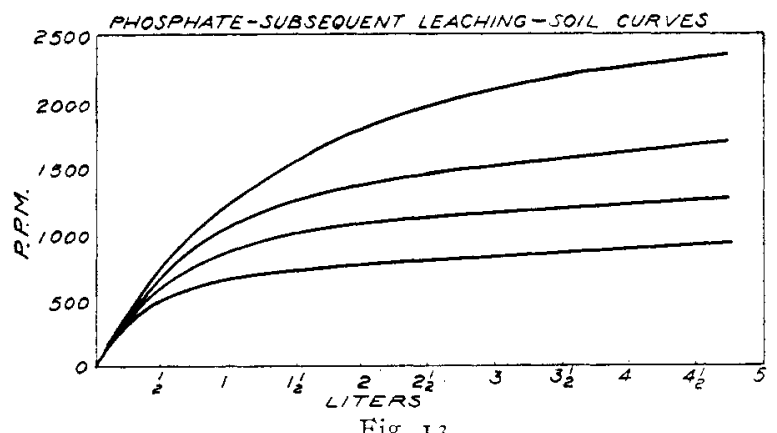

Here, again, as in the adsorption of phosphate, the soils require a much larger amount of water to bring them down to a constant than was the case with the potassium. But like the potassium, only a part of the total phosphate adsorbed has been removed when this constant is finally reached.

\section{Summary}

The study of these four Connecticut Valley soils has accomplished two purposes: Ist, it has presented the data, summarized in the foregoing curves, of the rate and extent of the adsorption of potassium and phosphate ions by these four soils, together with the rate and extent to which these adsorbed ions are subsequently leached out; and 2 nd, it has substantiated the results of Cameron. Schreiner. Failver. schloesing, and others, in the following points:

I. When soils are subjected to the leaching action of water. the concentration of potassium and phosphate ions in the soil extract approaches a constant. which appears to be fixed and definite for any given soil.

2. When soils are subjected to the action of soluble potassium and phosphate salts, the concentration of these salts in the soil extract is at first not materially increased. owing to the power of the soils to adsorb these salts, but as adsorption proceeds it becomes weaker, and a point is finally reached 
where the amount of soluble salts extracted in the soil extract is nearly equivalent to the amount applied.

3. The concentration of the potassium and phosphate ions in the soil extract approaches a low constant, which appears to be fixed and definite for each soil, when only a part of the adsorbed ions has been removed by the leaching action of water.

4. The constants attained by the four soils by the leaching action of water are very nearly alike, which would seem to indicate that the concentration of the potassium and phosphate ions in the soil solutions of the various soils were practically the same, and not at all dependent on the amount of adsorbed potassium or phosphate they originally contained.

5. These results substantiate the theory that the concentration of salts in the soil solution is very largely dependent on the specific adsorptive capacity of the individual soil.

6. These results, furthermore, tend to disprove the theory that the composition of the soil moisture, hence the adsorptive capacity of the soil, is determined primarily by the chemical composition of the soil, but tend rather to prove this quality to be dependent on the mechanical texture of the individual soil.

- Furthermore, inasmuch as these soils continue to adsorb small amounts of potassium and phosphate ions long after the approximate point of saturation has been reached; and as these soils continue to lose these potassium and phosphate ions in small amounts long after the soluble forms must have been entirely leached out: and as this latter point is reached long before all of the previously adsorbed potassium and phosphate ions have been leached out, it would appear that the soils were able to take up these ions from the solution in two distinct ways: Ist, by saturating itself with the ions, these undergoing no chemical change, and thus remaining readily soluble, and easily leached out; and $2 \mathrm{nd}$, by interacting with the salts, producing insoluble compounds 
which are reconverted into soluble forms on the applica. tion of water, but very slowly. Thus on the application of a salt in solution the soil first rapidly adsorbs the various ions for which it has an attraction, and in proportion to the strength of this attraction, and then proceeds slowly to interact with the salts to produce insoluble compounds. On the application of water to this soil, the soluble adsorbed salts would be quickly leached out, and then the insoluble compounds would in turn be very slowly rendered soluble, by the reversion of the previous reactions, and ultimately they, too, would pass off in the solution.

Acknowledgment is due to Dr. Ernest Anderson for suggesting this investigation, and to Dr. Anderson and Professor Morse for advice and further suggestions before its completion.

Massachusetts Agricultural College

June, IOI5 